\title{
Enzyme Deficiency in Cholesteryl Ester Storage Disease
}

\author{
Howard R. Sloan and Donald S. Fredrickson \\ From the National Heart and Lung Institute, National Institutes of Health, \\ Bethesda, Maryland 20014
}

\begin{abstract}
A B S T R A C T Cholesteryl ester storage disease has been shown to involve severe deficiency of acid cholesteryl ester hydrolase and triglyceride lipase activity in liver, spleen, and lymph node. The cholesteryl ester hydrolase was also deficient in aorta. Tissue storage of both cholesteryl esters and triglycerides is generalized. Both the lipid and enzymatic changes are very similar to those in Wolman's disease.
\end{abstract}

\section{INTRODUCTION}

Profound tissue accumulation of cholesteryl esters and triglycerides occur in two rare human diseases, Wolman's disease (1) and cholesteryl ester storage disease $(\mathrm{CESD})^{1}(2)$. Absence of hepatic acid lipase activity in both diseases has recently been reported $(3,4)$. Patients with Wolman's disease fail to thrive and usually die by 6 months of age. CESD, by contrast, does not appear to limit life expectancy; the four clear-cut examples of the disease have had in common only hepatomegaly and hypercholesterolemia (2). This difference in clinical expression has suggested that enzyme deficiency is generalized in Wolman's disease but localized to the liver, and possibly intestine, in CESD (2).

The death of the original patient with CESD has provided the first opportunity to determine that the breadth of tissue involvement in this disorder is also generalized and very similar to that in Wolman's disease. In this paper we report tissue lipid concentrations and a comparison of the activities of cholesteryl ester hydrolase and triglyceride lipase in a variety of tissues from controls, the patient with CESD, and one patient with Wolman's disease.

Received for publication 7 March 1972 and in revised form 19 April 1972.

${ }^{1}$ Abbreviations used in this paper: ACEH, acid cholesteryl ester hydrolase; ATGL, acid triglyceride lipase; CEH, cholesteryl ester hydrolase; CESD, cholesteryl ester storage disease; MGL, monoglyceride lipase; TGL, triglyceride lipase.

\section{METHODS}

Tissues obtained postmortem from a $21 \mathrm{yr}$ old patient with CESD (L. Mc.) (2) who died of aortic stenosis apparently unrelated to CESD, a 4 month old patient with Wolman's disease, $^{2}$ and controls were stored at $-20^{\circ}$. Cholesteryl (oleate-1-11. $\mathrm{C}$ ) and cholesteryl (palmitate-1- ${ }^{11} \mathrm{C}$ ) were prepared by reaction of cholesterol with the appropriate fatty acid chloride $\left(-1-{ }^{14} \mathrm{C}\right)(5,6)$; glyceryl- $\alpha$-monoleate- $1-{ }^{14} \mathrm{C}$ was prepared by the analogous reaction with glycerol. Glyceryl-trioleate-1 $1{ }^{14} \mathrm{C}$ was purchased from Amersham/Searle Corp., Arlington Heights, IIl., and all nonradioactive lipids from Applied Science Laboratories, Inc., State College, Pa. All lipid substrates were purified by column and thin-layer chromatography $(7,8)$. Qualitative and quantitative lipid analyses were performed as described by Kwiterovich, Sloan, and Fredrickson (8). Tissue cholesteryl esters were isolated by thin-layer chromatography and characterized by gas chromatography-mass spectrometry; an LKB 9000 system was employed with an ionizing voltage of $70 \mathrm{ev}$ and a source temperature of $270^{\circ}$. Samples were admitted either via a direct insertion probe or a gas chromatograph (3\% OV-1, isothermal at $220^{\circ}$ ). Protein was measured by the method of Lowry, Rosebrough, Farr, and Randall (9).

All tissues were homogenized at $0^{\circ}$ in $10 \mathrm{vol}$ of $0.15 \mathrm{M}$ buffer of appropriate $\mathrm{pH}$. A Teflon and glass homogenizer was used for liver, spleen, and lymph node; a Polytron (Brinkmann Instruments, Inc., Westbury, N. Y.) provided uniform homogenization of aorta (four 10-sec periods at setting 5). Cholesterol ester hydrolase ( $\mathrm{CEH})$, triglyceride lipase (TGL), and monoglyceride lipase (MGL) activities were determined by the method of Krauss. ${ }^{3}$ Each substrate (cholesteryl ester, $1.0 \mathrm{mg}$; triglyceride, $100 \mathrm{mg}$; or monoglyceride, $1.0 \mathrm{mg}$ ) was suspended in a mixture of $0.6 \mathrm{ml}$ of $1 \%$ Triton X-100, $1.0 \mathrm{ml}$ of $20 \%$ serum albumin (fatty acidpoor; Miles Laboratories, Inc., Kankakee, I11.), and $10.4 \mathrm{ml}$ of $0.15 \mathrm{M}$ buffer of the appropriate $\mathrm{pH}$. An emulsion of homogeneous appearance was produced by $1 \mathrm{~min}$ sonification at $70 \mathrm{k}$ (Heat Systems-Ultrasonics, Inc., Plainview, N. Y., Model W-1850). $0.9 \mathrm{ml}$ was incubated with $0.1 \mathrm{ml}$ of enzyme source (containing $5-20 \mathrm{mg}$ of tissue) at $37^{\circ}$. It was ascertained that hydrolysis of triglyceride by normal liver proceeds linearly for $2 \mathrm{hr}$ at either $\mathrm{pH} 4.0$ or 8.6 and that hydrolysis of cholesteryl ester was linear for at least $3 \mathrm{hr}$ at either $\mathrm{pH} 4.0$ or 7.4. We, therefore, used incubation periods of $1.5 \mathrm{hr}$ in the determination of TGL and MGL

${ }^{2}$ Kindly provided by Dr. Allen Crocker.

${ }^{3}$ Krauss, R. M. In preparation. 
TABLE I

Acid Hydrolase Activity in Liver, Spleen and Lymph Node

\begin{tabular}{|c|c|c|c|c|c|c|}
\hline \multirow[b]{3}{*}{ Tissue } & \multirow[b]{3}{*}{ Source } & \multicolumn{5}{|c|}{ Acid hydrolase activity } \\
\hline & & \multicolumn{2}{|c|}{ Cholesteryl } & \multicolumn{3}{|c|}{ Glyceryl } \\
\hline & & Oleate & Palmitate & Trioleate & Tripalmitate & Mono-oleate \\
\hline \multicolumn{7}{|c|}{ pmoles substrate cleaved/mg wet tissue per $\mathrm{hr}$} \\
\hline \multicolumn{7}{|l|}{ Liver } \\
\hline CES & & 1.00 & 1.70 & 660 & 1,530 & 71.6 \\
\hline Woln & n's & 0.38 & 0.98 & 460 & 980 & 26.2 \\
\hline Norn & & $107 \pm 23$ & $150 \pm 32.8$ & $5,750 \pm 3,600$ & $8,650 \pm 3,430$ & $247 \pm 97$ \\
\hline Niem & nn-Pickł & $107 \pm 41$ & $168 \pm 37$ & $11,700 \pm 2,200$ & $26,380 \pm 3,600$ & \\
\hline Gauc & er's§ & & 136 & 5,100 & 7,670 & \\
\hline \multicolumn{7}{|c|}{ Spleen } \\
\hline CES & & 7.6 & & 1,060 & & \\
\hline Woln & an's & 1.3 & & 219 & & \\
\hline Cont & ls" & $203 \pm 19$ & & $19,400 \pm 3,320$ & & \\
\hline \multicolumn{7}{|c|}{ Lymph node } \\
\hline CES & & 3.54 & & 663 & & \\
\hline Woln & an's & $<0.1$ & & 274 & & \\
\hline Cont & $1 \mathbf{s}^{\prime \prime}$ & $108 \pm 47$ & & $10,430 \pm 4,340$ & & \\
\hline
\end{tabular}

* Mean \pm SD of four to six subjects, age 22-59, deceased from vascular disease or trauma.

$\ddagger$ Mean \pm SD of three patients with Niemann-Pick disease: type A (3 yr), type C (13 yr), and type D (9.5 yr) (13).

\$ A 2 yr old patient with acute neuronopathic Gaucher's disease.

"Mean \pm SD of values obtained in postmortem tissues from five patients: three with Niemann-Pick disease, types $\mathrm{C}$ or $\mathrm{D}$, one with $\mathrm{G}_{\mathrm{M} 1}$ gangliosidosis, and one with vascular disease.

activities and $3 \mathrm{hr}$ for $\mathrm{CEH}$ activities. The procedure of Schotz, Garfinkel, Huebotter, and Stewart (10) was employed to terminate the reactions and extract the liberated ${ }^{14} \mathrm{C}$-fatty acids into $0.1 \mathrm{M} \mathrm{KOH}$. Portions of the extract were counted in a scintillation spectrometer in $10 \mathrm{ml}$ of Instagel (Packard Instrument Co., Inc., Downers Grove, Ill.). $\beta$-N-acetyl-galactosaminidase, sphingomyelinase, and $\beta$ galactosidase activities were determined as previously described $(11,12)$.

\section{RESULTS}

Tissue lipid content. The lipid contents of three tissues were compared with average normal values $(2,13)$. Expressed as milligram lipid per gram wet tissue, the cholesteryl ester concentrations in CESD, Wolman's disease, and normal, respectively, were: liver, 94.6, 28.0, and 1.0 ; spleen, $1.9,3.9$, and 0.5 ; and lymph node, 4.2, 12.4 , and 0.4 . The triglyceride concentrations were: liver, $33.4,84.0$, and 19.4 ; spleen, $32.5,3.5$, and $<0.5$; and lymph node, 4.1, 86.9, and 6.1. The esterified sterol in the patients' livers was $>99 \%$ cholesterol; oleic acid was the predominant fatty acid. Thin-layer chromatography revealed no significant quantities of partial glycerides. Concentrations of lipids, and of the enzyme activities to be described now, were also calculated according to tissue protein content. The relative values did not differ from those referred to wet weight of tissue.
Activities of ACEH and acid triglyceride lipase ( $A T G L)$. In CESD liver, spleen, and lymph node, the ACEH activity was only $1-3 \%$ of normal; the ATGL activity was $<10 \%$ of controls (Table I). The residual activities of both enzymes were somewhat lower in Wolman's disease. The activities presented in Table I are corrected for dilution of the radioactive substrate by the endogenous cholesteryl esters or triglycerides in the homogenates on the assumption that complete mixing occurred. In the ATGL assay, the ${ }^{14} \mathrm{C}$-triolein or ${ }^{14} \mathrm{C}$-tripalmitin added was 50-100 times the endogenous substrate present in any incubation mixture. The correction for dilution by endogenous substrate was negligible. The ATGL activities obtained in mixtures of homogenates of control and abnormal tissues were within $5 \%$ of those predicted from the sum of the activity in each component.

In the ACEH assay, the quantity of endogenous cholesteryl ester in homogenates of diseased tissue sometimes exceeded the amount of added ${ }^{14} \mathrm{C}$-ester. The corrected activities obtained in mixtures of different homogenates were within $10-20 \%$ of the predicted values. This larger variation suggested that mixing of the endogenous and exogenous substrate was incomplete. Therefore, acetoneether powders (14) of liver were prepared. These retained $3-10 \%$ of the endogenous cholesteryl esters or 
triglycerides and approximately $80 \%$ of the $\mathrm{ACEH}$ and ATGL activities of the starting homogenates. When mixtures of acetone powders from control and abnormal livers were incubated, the activities of ATGL and ACEH were within $5 \%$ of the predicted values.

These results indicate that the deficiencies of ATGL and ACEH activities in both CESD and Wolman's disease are not due to dilution of the added labeled substrate. They also suggest that the abnormal tissues do not lack a soluble activator present in the controls.

Reversibility of $A C E H$ or $A T G L$ reactions. It has been recently reported that cholesteryl esters are synthesized in liver at acid $\mathrm{pH}$ in the absence of added cofactors (15). We, therefore, determined whether labeled cholesteryl esters and triglycerides are formed under the conditions used for assay of ACEH and ATGL activities.

The substrate emulsions were prepared as described in the Methods. In the first, however, ${ }^{14} \mathrm{C}$-cholesteryl oleate was replaced with an equivalent amount of unlabeled cholesteryl oleate and $11 \mathrm{mg}$ of unlabeled oleic acid. The second contained $100 \mathrm{mg}$ each of unlabeled triolein and oleic acid. Both emulsions also contained $4.2 \mu \mathrm{Ci}$ of carrier-free oleic acid- $1{ }^{14} \mathrm{C}$ (SA $60 \mu \mathrm{Ci} / \mu$ moles). These emulsions were then incubated for 180 and $90 \mathrm{~min}$, respectively, with homogenates of liver from either a control or the patients with CESD or Wolman's Disease. Reactions were terminated by the addition of $20 \mathrm{vol}$ of chloroform-methanol $(2: 1)$. Portions of the washed chloroform phases (8) were applied to thin-layer plates of Silica Gel.

Two-step development (petroleum ether: diethyl ether: glacial acetic acid, $95: 5: 1$, followed by chloroform: acetone: glacial acetic acid, $184: 4: 1$ ) was employed to separate cholesteryl esters, triglycerides, and free fatty acids. The latter contained approximately $90 \%$ of the added ${ }^{14} \mathrm{C}$-radioactivity. The radioactivity recovered in cholesteryl esters and triglycerides was the same as that

TABLE II

Cholesterol and Cholesteryl Ester Content and Acid Cholesteryl Ester Hydrolase Activity in Aorta

\begin{tabular}{lcccc}
\hline Source* & Age & Cholesterol $\begin{array}{c}\text { Cholesteryl } \\
\text { ester }\end{array}$ & $\begin{array}{c}\text { Enzyme } \\
\text { activity }\end{array}$ \\
\hline & $y r$ & $m g / g$ wet weight & $\begin{array}{c}\text { units } \$ \text { mg } \\
\text { protein } / h r\end{array}$ \\
CESD & 21 & 14.5 & 6.5 & 0.25 \\
Control & 19 & 9.4 & 1.5 & 4.05 \\
Control & 69 & 8.6 & 2.4 & 6.23 \\
\hline
\end{tabular}

* Sections of abdominal aorta frozen at postmortem; the 19 yr old control died after trauma, the $69 \mathrm{yr}$ old control from acute myocardial infarction.

$\ddagger$ Picomoles cholesteryl oleate cleaved. in controls incubated without added liver $(<0.01 \%$ of the added ${ }^{14} \mathrm{C}$ ). There was no evidence of synthesis of either cholesteryl esters or triglycerides.

Aorta. ACEH and ATGL activities were also determined in aortic tissue from the patient with CESD and two controls. The sections of aorta used were free of visible atheromatosis and stripped of adventitia. ACEH activity in the patient's aorta was definitely depressed (Table II). Measurable ATGL activity was not detected in any of the aortas.

Other lysosomal enzymes. The activities of sphingomyelinase, $\beta$ - $\mathrm{N}$-acetyl-galactosaminidase and $\beta$-galactosidase in liver from both patients were all within normal limits.

\section{DISCUSSION}

Cholesteryl ester hydrolase activities with neutral (6) and acidic $(15,16) \mathrm{pH}$ optima have been described in rat liver as has an acid lipase (16). For $\mathrm{CEH}$ activity, we initially used the assay developed by Deykin and Goodman (6); the method we finally employed yielded specific enzymatic activities that were approximately $25 \%$ greater. We found the following $\mathrm{CEH}$ activities in human liver, expressed as a per cent of that obtained at $\mathrm{pH}$ $4.0: \mathrm{pH} 3.5,93 \% ; 4.5,90 \%, 5.0,80 \% ; 5.5,65 \% ; 7.4$, $1.0 \%$. The hydrolysis of triglyceride by liver homogenates proceeded about seven times faster at $\mathrm{pH} 4.0$ than at 8.6. There was no difference in the liver $\mathrm{CEH}$ activities obtained at $\mathrm{pH} 7.4$ in CESD, Wolman's disease, and controls. Our observations that ACEH and ATGL activities are deficient in CESD and Wolman's disease while neutral CEH and TGL activities are normal indicate that the two enzymatic activities reside on different proteins.

During the course of this study, Burke and Schubert briefly described the absence of ACEH and ATGL activities at $\mathrm{pH} 4.4$ in liver from one patient each with CESD and Wolman's disease (4). Our results are in qualitative agreement. With the isotopic technique, however, we found a lower $\mathrm{pH}$ optimum and also observed that tissue hydrolase activities two- to three-fold greater than blank controls values were present in both diseases.

Both the enzymatic and chemical data indicate that CESD and Wolman's disease may be phenotypic variants of mutation at the same genetic locus. Our observation that slightly greater residual enzyme activities are present in CESD does not allow the conclusion that such minor differences account for additional organomegaly, adrenal calcification, and the early death from obscure cause that distinguish Wolman's disease from its more benign counterpart.

The coupled loss of ACEH and ATGL activities suggests that they may reside on the same protein or depend upon a common protein subunit. A difference in 
apparent stability of the enzyme activities was observed. At $37^{\circ}$ hydrolysis of cholesteryl esters was linear for at least $15 \mathrm{hr}$, provided that less than $5 \%$ of added substrate was utilized. ATGL activity was linear for only $2 \mathrm{hr}$, however, even though less than $0.5 \%$ of added substrate was hydrolyzed. Hydrolysis of monoglycerides at acid $\mathrm{pH}$ appeared to be decreased in the two diseases (Table I). The range of control values was so wide, however, that the significance of the apparent depression could not be evaluated.

The young female patient with CESD had an extraordinary degree of aortic and coronary atherosclerosis. In the sample of her aorta, the ACEH activity was clearly less and the cholesterol and cholesteryl ester concentrations somewhat higher than those in the two controls (Table II). The triglyceride content of her aorta appeared to be markedly elevated from a thin-layer chromatogram, but insufficient. material was available for quantitative analysis.

\section{REFERENCES}

1. Wolman, M., V. V. Sterk, S. Gatt, and M. Frenkel. 1961. Primary familial xanthomatosis with involvement and calcification of the adrenals. Pediatrics. 28: 742.

2. Sloan, H. R., and D. S. Fredrickson. 1972. Rare familial diseases with neutral lipid storage. In The Metabolic Basis of Inherited Disease. J. B. Stanbury, J. B. Wyngaarden, and D. S. Fredrickson, editors. 3rd edition. McGraw Hill, Inc., New York. 808.

3. Patrick, A. D., and B. D. Lake. 1969. Deficiency of an acid lipase in Wolman's disease. Nature (Lond.). 222: 1067.

4. Burke, J. A., and W. K. Schubert. 1971. Deficient activity of acid lipase in cholesterol ester storage disease. J. Lab. Clin. Med. 78: 988. (Abstr.)
5. Wood, T. R., F. L. Jackson, A. R. Baldwin, and H. E. Longenecker. 1944. The preparation of some unsaturated fatty acid chlorides. J. Am. Chem. Soc. 66: 287.

6. Deykin, D., and D. S. Goodman. 1962. The hydrolysis of long-chain fatty acid esters of cholesterol with rat liver enzymes. J. Biol. Chem. 237: 3649.

7. Skipski, V. P., and M. Barclay. 1969. Thin-layer chromatography of lipids. Methods Enzymol. 14: 530.

8. Kwiterovich, P. O., H. R. Sloan, and D. S. Fredrickson. 1970. Glycolipids and other lipid constituents of normal human liver. J. Lipid Res. 11: 322.

9. Lowry, O. H., N. J. Rosebrough, A. L. Farr, and R. J. Randall. 1951. Measurement of protein with the Folin phenol reagent. J. Biol. Chem. 193: 265.

10. Schotz, M. C., A. S. Garfinkel, R. J. Huebotter, and J. E. Stewart. 1970. A rapid assay for lipoprotein lipase. J. Lipid Res. 11: 68.

11. Sloan, H. R., B. W. Uhlendorf, C. B. Jacobson, and D. S. Fredrickson. 1969. $\beta$-galactosidase in tissue culture derived from human skin and bone marrow: enzyme defect in $\mathrm{G}_{\mathrm{M} 1}$ gangliosidosis. Ped. Res. 3: 532.

12. Sloan, H. R., B. W. Uhlendorf, J. N. Kanfer, R. O. Brady, and D. S. Fredrickson. 1969. Deficiency of sphingomyelin-cleaving enzyme activity in tissue cultures derived from patients with Niemann-Pick disease. Biochem. Biophys. Res. Commun. 34: 582.

13. Fredrickson, D. S., and H. R. Sloan. 1972. Sphingomyelin lipidoses: Niemann-Pick disease. In The Metabolic Basis of Inherited Disease. J. B. Stanbury, J. B. Wyngaarden, and D. S. Fredrickson, editors. 3rd edition. McGraw Hill, Inc., New York.

14. Morton, R. K. 1955. Methods of extraction of enzymes from animal tissues. Methods Enzymol. 1: 34.

15. Stokke, K. T. 1971. Evidence for a new cholesterol esterase in human liver. Scand. J. Clin. Lab. Invest. Suppl. 118. 27: 50 .

16. Stoffel, W., and H. Greten. 1967. Studies on lipolytic activities of rat liver lysosomes. Hoppe-Seyler's $Z$. Physiol. Chem. 348: 1145. 